\title{
Selective Inhibition by Pantoyl Lactone and Butyl Alcohol of the Initiation of DNA Replication in E. coli
}

\author{
Yoshihiro Yoshryama, Kazuo Nagai, Hideaki Some and Gakuzo Tamura \\ Department of Agricultural Chemisty, Faculty of Agriculture, The University of Tokyo, Tokyo \\ Received October 14, 1972
}

\begin{abstract}
We studied action mechanisms of pantoyl lactone and butyl alcohol on the macromolecular synthesis of $E$. coli. Protein synthesis was not significantly suppressed by these agents. DNA synthesis was more remarkably affected than RNA synthesis by them. Synchronous cultures of $E$. coli were subsequently used to investigate the inhibition of DNA replication with these agents. It was consequently shown that these agents inhibit the initiation of a new cycle of DNA replication in this organism but permit the completion of DNA replication initiated before addition of these agents to the medium.
\end{abstract}

Very low doses of UV-light cause $E$. coli $\mathrm{B}$ as well as lon $^{-}$mutants of $E$, coli $\mathrm{K}-12$ to grow into long, multinucleate, nonseptate and filamentous cells on rich media, therefore preventing formation of macrocolonies. ${ }^{1,2)}$ It is well known that this kind of UV-damage is reversed by pantoyl lactone, ${ }^{3)}$ but the mechanism involved is not known. Our previous studies have shown that phenethyl alcohol and butyl alcohol possess division-stimulating activities which are similar to those found with pantoyl lactone. ${ }^{4}$

Treick and Konetzka ${ }^{5}$ reported that phenethyl alcohol inhibits the initiation of a new cycle of DNA replication in E. coli but permits the completion of DNA replication initiated before addition of this agent into the medium. Learning from these results, we examined the effect of pantoyl lactone and butyl alcohol on the macromolecular synthesis of $E$. coli. It was found that these agents inhibited most markedly DNA synthesis among macromolecular synthesis examined and blocked selectively the initiation of DNA replication.

\section{MATERIALS AND METHODS}

Bacterial growth. E. coli W2252 (thy-, met $^{-}$) (given by Dr. T. Beppu, University of Tokyo) was incubated at $37^{\circ} \mathrm{C}$ with aeration in the following medium. Medium GT; glucose $2 \mathrm{~g}, \mathrm{KCl} 2.02 \mathrm{~g}, \mathrm{NH}_{4} \mathrm{Cl} 1.98 \mathrm{~g}, \mathrm{CaCl}_{2}$ $14.7 \mathrm{mg}, \mathrm{MgCl}_{2} 142 \mathrm{mg}, \mathrm{Na}_{2} \mathrm{SO}_{4} 398 \mathrm{mg}, \mathrm{FeCl}_{3} 2.7 \mathrm{mg}$,
Tris- $\mathrm{HCl} 12.1 \mathrm{~g}$, thymine $30 \mathrm{mg}$, methionine $50 \mathrm{mg}$ per liter; the $\mathrm{pH}$ was adjusted to 7.6 .

Protein and nucleic acid syntheses. Cells of $E$. coli W2252 grown overnight in the medium GT were transferred into 50-fold volumes of fresh medium and incubated at $37^{\circ} \mathrm{C}$. At the logarithmic phase of growth, the cell suspension was divided into $9.7 \mathrm{ml}$ portions in L-tubes at $0^{\circ} \mathrm{C}$. After $10 \mathrm{~min}$ of incubation at ${ }^{37} 7^{\circ} \mathrm{C}, 0.5 \mu \mathrm{C}$ of ${ }^{14} \mathrm{C}$-amino acids or $0.5 \mu \mathrm{C}$ of ${ }^{24} \mathrm{C}$ adenine was added simultaneously with $50 \mu \mathrm{g}$ of adenine to each culture. At the same time, pantoyl lactone or butyl alcohol was supplemented into the culture. Nucleic acids and protein were fractionated from $3 \mathrm{ml}$ of samples according to the method of Schmidt and Thannhauser.63 The radioactivities of the fractionated materials were determined with a GM counter.

Synchronous cultures. Synchronous bacterial cultures were prepared by the method described by Cutler and Evans." The cells of E. coli W2252 grown overnight in the medium GM were transferred into fresh medium and incubated at $37^{\circ} \mathrm{C}$. Cells were harvested by membrane filter (Sartorius, $0.45 \mu$ ) at 15 min after reaching the initial stationary phase as controlled by optical density measurements, and were then incubated into fresh medium. The above procedure was repeated once more. Subsequent cultures exhibited stepwise cellular divisions as expected for synchronous cultures. The number of viable cells was determined by colony-formation on nutrient agar plates consisting of $7 \mathrm{~g}$ of meat extract, $10 \mathrm{~g}$ of peptone, $3 \mathrm{~g}$ of $\mathrm{NaCl}$ per liter, $\mathrm{pH} 7.0$.

${ }^{14} C$-thymine incorporation. Synchronized cells were transferred into the medium GT supplemented 
with $0.03 \mu \mathrm{C}$ per ml of ${ }^{14} \mathrm{C}$-thymine and were incubated at $37^{\circ} \mathrm{C}$ with shaking. Aliquots $(1 \mathrm{ml})$ were withdrawn at intervals and combined with $1 \mathrm{ml}$ of $10 \%$ cold trichloroacetic acid. After standing for $60 \mathrm{~min}$ in the cold, cells were centrifuged at $3000 \times g$ for $10 \mathrm{~min}$ and washed with an equal volume of cold trichloroacetic acid. After the precipitates were collected and suspended in $1 \mathrm{ml}$ of $1 \mathrm{~N} \mathrm{KOH}$, the radioactivity was counted by a Horiba Liquid Scintillation spectrometer.

\section{RESULTS}

Effects of pantoyl lactone and butyl alcohol on the macromolecular synthesis of E. coli.

The effect of pantoyl lactone on protein and nucleic acid synthesis in $E$. coli W2252 cells grown exponentially in culture is illustrated in

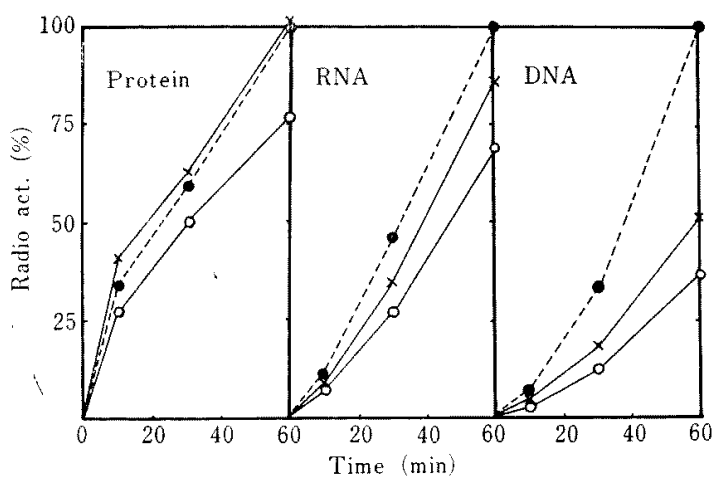

FIG. 1. Effect of Pantoyl Lactone on the Macromolecular Synthesis of $E$. coli.

After addition of radioactive materials, the culture was divided into three parts; control $(--), 0.10 \mathrm{M}$ pantoyl lactone added $(x-x), 0.15 \mathrm{M}$ pantoyl lactone added $(\mathrm{O}-\mathrm{O})$.

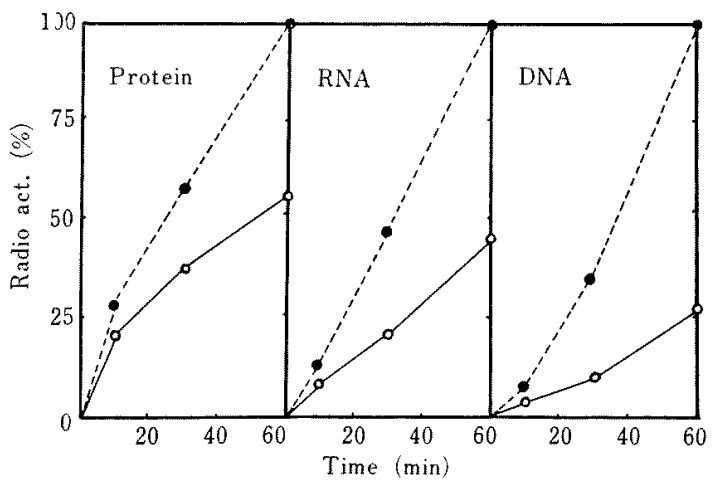

FIG. 2. The Effect of Butyl Alcohol on the Macromolecular Synthesis of E. coli.

closed circles, control; open circles, $0.8 \%$ butyl alcohol
Fig. 1. RNA synthesis was somewhat more sensitive to pantoyl lactone than protein synthesis. It is also shown that DNA synthesis was more remarkably affected than RNA synthesis. Pantoyl lactone inhibited, at a concentration of $0.10 \mathrm{M}$ protein, RNA and DNA synthesis by zero, 16 and $48 \%$, respectively. We then examined the effect of butyl alcohol on the macromolecular synthesis of $E$. coli; this agent recovers the UV-damaged cell division of $E$. coli $\mathrm{B}$ like pantoyl lactone. It was observed that DNA synthesis was most sensitive to butyl alcohol as in the case of pantoyl lactone (Fig. 2).

Inhibition of DNA synthesis with pantoyl lactone or butyl alcohol

We then studied the effect of pantoyl lactone or butyl alcohol on DNA replication in synchronized cells of $E$. coli W2252 obtained

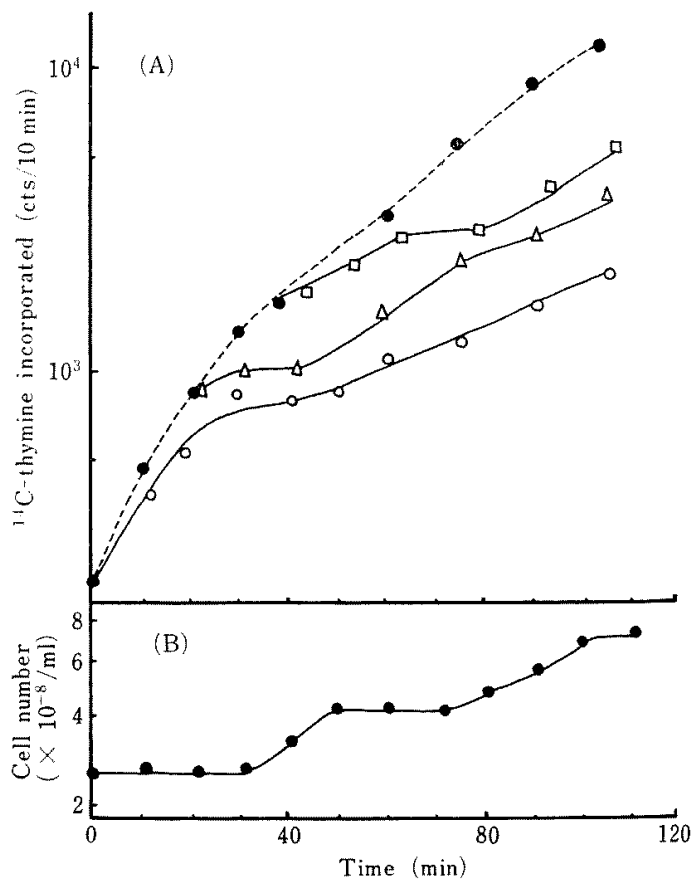

FIG. 3. The Effect of Pantoyl Lactone on DNA Synthesis of E. coli Growing Synchronously.

(A) $0.1 \mathrm{M}$ pantoyl lactone was added to the synchronous culture of $E$. coli at $O(O), 20(\triangle)$ and $40(\square) \mathrm{min}$. A culture without the drug is indicated by closed circles.

(B) Growth curve of a synchronous culture of $E$. coli. 


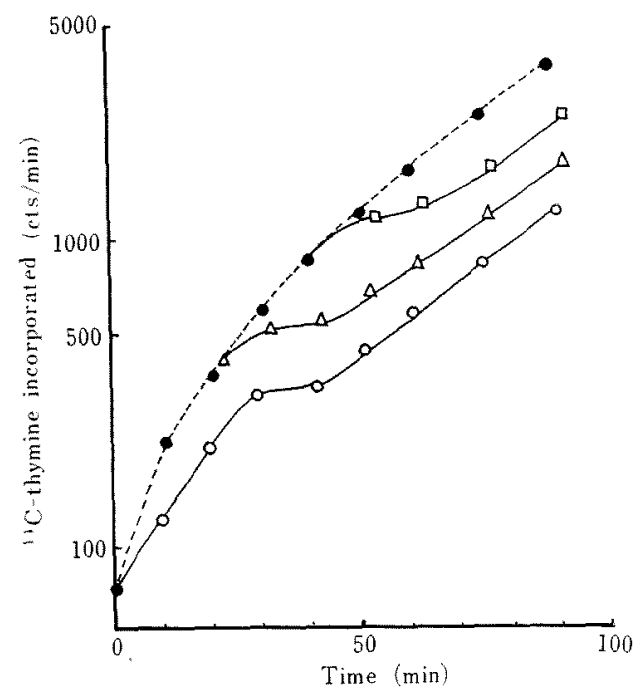

Fia. 4. The Effect of Butyl Alcohol on DNA Synthesis of E. coli Growing Synchronously.

Synchronized cells were transferred into the medium supplemented with ${ }^{14} \mathrm{C}$-thymine and were incubated at $37^{\circ} \mathrm{C} .1 \%$ butyl alcohol was added to the culture at $0(0), 20(\triangle)$ and $40(\square) \mathrm{min}$. A culture without the drug is indicated by closed circles. Aliquots were withdrawn at intervals and the radioactivities were measured.

by the stationary-phase synchrony method. ${ }^{7}$ As indicated in Fig. 3-B, the cells were synchronized with a generation time of $45 \mathrm{~min}$. As can be seen in Fig. 3-A, if pantoyl lactone was added into the synchronous culture at zero time and $20 \mathrm{~min}$, DNA synthesis was prevented at $25 \mathrm{~min}$, while the addition of the agent at $40 \mathrm{~min}$ allowed DNA synthesis up to $65 \mathrm{~min}$. Cells of $E$. coli growing in a glucose medium with a generation time of $45 \mathrm{~min}$ possess chromosomes that are almost half-replicated. ${ }^{8)}$ Considering these findings, the continuation of DNA synthesis in the presence of pantoyl lactone suggests that the compound might not affect the polymerization involved in DNA replication, once the process had been initiated. As shown in Fig. 4, it appears that butyl alcohol also inhibits the initiation of a new cycle of DNA replication like pantoyl lactone. It may be very probable that a strict range of drug concentration might be required to inhibit the initiation of DNA replication. Concentrations lower than the critical one may allow the initiation of DNA synthesis; concentrations greater than the critical one may markedly inhibit the synthesis of macromolecules and therefore kill the cell. ${ }^{4}$

\section{DISCUSSION}

It has been known that the UV-damage is reversed by pantoyl lactone. The present results indicated that pantoyl lactone and butyl alcohol affected most remarkably the DNA synthesis among macromolecular syntheses studied in E. coli W2252. Furthermore, it was demonstrated in synchronized cultures that these agents inhibit initiation of a new cycle of DNA replication in $E$. coli but permit the completion of DNA replication initiated before addition of these agents into the medium.

The UV-exposed cells recover their division ability by the addition of phenethyl alcohol $^{4}$ which is known as an inhibitor of DNA synthesis. In E. coli, phenethyl alcohol has been reported to permit the completion of DNA replication but to inhibit the initiation of new DNA replication cycle. ${ }^{5)}$ Contrary to such an effect of phenethyl alcohol, several other inhibitors of DNA synthesis such as mitomycin $C$, bleomycin and nalidixic acid have been known to inhibit DNA synthesis of bacteria immediately after addition of chemicals into the culture at any time of the cell cycle $^{9 \sim 11)}$ and to cause the filament formation of bacteria. ${ }^{10,12,13)}$ These agents, at concentrations tested, did not stimulate cell division of UV-irradiated $E$. coli B but suppressed the formation of colonies.

Considering the above informations as well as the present results, it may be concluded that the chemicals such as pantoyl lactone, butyl alcohol and phenethyl alcohol stimulate or recover the cell division ability in UVirradiated cells of $E$. coli B by suppressing selectively the initiation of DNA replication.

Acknowledgement. This work was partly supported by the grant from the Waksman Foundation of Japan (No. 45-4). 


\section{REFERENCES}

1) F. L. Gates, Science, 77, 350 (1933).

2) H. I. Adler and A. A. Hardigree, J. Bacteriol, 87, 720 (1964).

3) H. I. Adler and A. A. Hardigree, Radiation Res., 25, 92 (1965).

4) Y. Yoshiyama, K. Nagai, K. Arima and G. Tamura, Agr. Biol. Chem. (in press).

5) R. W. Treick and W. A. Konetzka, J. Bacteriol., 88, 1580 (1964).

6) G. Schmidt and S. T. Thannhauser, J. Biol. Chem., 161, 83 (1945).

7) R. G. Cutler and J. E. Evans, J. Bacteriol., 91,
469 (1966).

8) D. J. Clark, The Regulation of DNA Replication and Cell Division in $E$. coli $\mathrm{B} / \mathrm{r}$, Cold Spring Harbor Symposium on Quant. Biol., 33, 823 (1968).

9) S. Shiba, A. Terawaki and J. Kawamata, Nature, 183, 1056 (1959).

10) H. Suzuki, K. Nagai, H. Yamaki, N. Tanaka and H. Umezawa, J. Antibiot., 21, 379 (1968).

11) W. A. Goss, W. H. Deitz and T. M. Cook, J. Bacteriol., 89, 1068 (1965).

12) H. Suzuki, J. Pangborn and W.W. Kilgore, ibid., 93, 683 (1967).

13) W. A. Goss, W. H. Deitz and T. M. Cook, ibid., 88, 1112 (1964). 